\title{
DISCUSSION
}

\section{MIND MAPS IN EFL SPEAKING CLASSES: A CASE STUDY AT UNIVERSITY OF FOREIGN LANGUAGE STUDIES THE UNIVERSITY OF DANANG}

\author{
Phan Van Hoa*, Ngo Thi Hien Trang \\ University of Foreign Language Studies - The University of Danang
}

Received 12 October 2020

Revised 20 October 2020; Accepted 29 November 2020

\begin{abstract}
Speaking, one of the two productive skills, has been paid much attention to by first-year students at the Faculty of English, University of Foreign Language Studies - The University of Danang (FE, UFLS - UD). There are a variety of strategies and techniques assisting EFL teachers and learners, and mind mapping technique is among these which could be implemented to improve teaching and learning performances in general and speaking skill in particular. Mind maps are being taken advantage of by EFL students in classes to improve their speaking skill. In this study, the researchers have assumed that mind maps have the facilitating impact on the oral speech performance of the first-year students at FE, UFLS - UD. We have conducted this research quantitatively and qualitatively whose data is from interview questions and a set of questionnaires for first-year students, and the researchers' classroom observation. This is a case study which aims to explore the reality of using mind maps including the frequency, speaking stages, and freshmen's attitudes when utilizing this technique to enhance this skill. Its suggestions could be applied in teaching and learning English speaking skill effectively.
\end{abstract}

Keywords: attitudes, first-year students, frequency, mind maps, speaking skill, stages.

\section{Introduction}

Being aware of the importance of English language skills consisting of reading comprehension, listening comprehension, writing, and speaking in the era of globalization and integration, students at FE, UFLS - UD are using different learning techniques to improve these four skills. Richard and Rodgers (2001) state that in the traditional methods, the speaking skill was ignored in the classrooms where the emphasis was on reading and writing skills. In Vietnam, since the national exam to graduate from high schools and entrance one to universities is being conducted in written

\footnotetext{
* Corresponding author. Tel.: (84) 903.581.228

Email: hoauni@gmail.com
}

forms and focus on vocabulary, grammar, reading comprehension, and writing; therefore, in a typical lesson on English, high school teachers tend to introduce vocabularies and explain grammatical rules that high school students have to learn by heart and do written exercises on textbooks, which means students spend most time studying these language components, and two language skills including writing and reading, except for speaking and listening. This teaching and learning method leans on Grammar-Translation method where reading and writing are the important skills, speaking and listening skills are not of great significance. Therefore, first-year students at FE, UFLS - UD encounter certain difficulties when acquiring these two skills. There is an 
assumption that speaking skill plays a vital role in seeking good job opportunities and is mostly needed to communicate within the international market. According to Baker and Westrup (2003), students with good English speaking skill would have better job opportunities, and get promoted, or even pursue their studies. The researchers have seen the difficulties in speaking that most first-year students confront with such as the lack of lexical resources, and idea generating skill. Furthermore, students also struggle to develop strong EFL speaking skill due to the complexity of the language, the differences between English and the mother tongue, and the shortage of chances to practice speaking English frequently and in different contexts according to Nunan (1999), Ellis (2008) and Shumin (2002), respectively.

To solve the problems, the researchers took advantage of mind maps. Based on the theory of mind-map, in the study of Nasution (2020), the result shows that mind mapping techniques better improve the students' speaking skill and this improvement is influenced by six factors namely interesting teaching media, interesting material, attractive classroom activities, enjoyable classroom management, attractive teacher's approach, and teacher strategy. Rachmawati, Nugrahaeni, and Mauludiyah (2020) also announce their findings that mind mapping strategy is effective in learning Arabic, especially in learning speaking skills, because this technique gives students the courage to bring out new vocabulary that they must master. The results were known from the difference between students' attitude and effectiveness of mind mapping before using this instructional strategy. Mirza (2017) and Anggraeni (2019) also take advantage of this method in teaching foreign languages, particularly in developing speaking skill for high school and university students. After being guided the use of mind-map by these two language teachers, the test performance of the groups using mind-map in studying is significantly higher than the other ones. They said that using mind-map before their speaking performances is really effective since they are well-prepared for lexical resources and ideas related to the speaking topics. In summary, using mind maps in teaching and learning process has been researched in some articles. However, the investigation into the reality of using this technique including the frequency, speaking stages, and freshmen's attitudes in speaking of first-year students at FE, UFLS - UD has not been done so far. For the reasons above, the study entitled "Mind Maps in EFL Speaking Classes: A Case Study at University of Foreign Language Studies" was carried out.

\section{Literature Review}

Definitions of "speaking" in language teaching and learning have been stated by many researchers. Speaking is the process of making and sharing meanings which use verbal and non-verbal symbols in different contexts (Chaney \& Burk, 1998). According to Burns and Joyce (1997), they define speaking as an interactive process of making meanings which consists of producing, receiving, and processing information. Howarth (2001) also regards speaking as a two-way process including a true communication of opinions, information, or emotions. The role of speaking skill in language learning has also been confirmed by researchers in this field. According to Richard (2008), speaking is a crucial skill in language learning which enables language learners to communicate by expressing their viewpoints and giving responses. Heaton (1988) proposes that in the teaching of speaking, learners must master 
the three components of speaking, namely fluency, accuracy, and comprehensibility. Therefore, language teachers and learners have to make efforts to select the suitable and effective methods facilitating the achievement of these three speaking components.

Techniques to facilitate the process of teaching and learning speaking skill are varied and mind mapping technique is one of them. Buzan (2006, p. 103) states that mind mapping technique is "a creative thinking instrument which reflects natural work brain. Mind map enables the brain to use all pictures and its association in radial design". What could be inferred from his definition of mind mapping technique is that the way of drawing a mind map is similar to the way the brain functions. Key word or topic will be in the center of the map and supporting ideas can spread outward on branches of the map. Buzan (2005) also advocates that mind mapping technique is an extremely effective tool of taking notes. Mind maps show not only facts but also the overall structure of a subject and the relative importance of the individual part of it. If students have their own mind maps, it will be easy for them to recall their memory and learn visual memory.

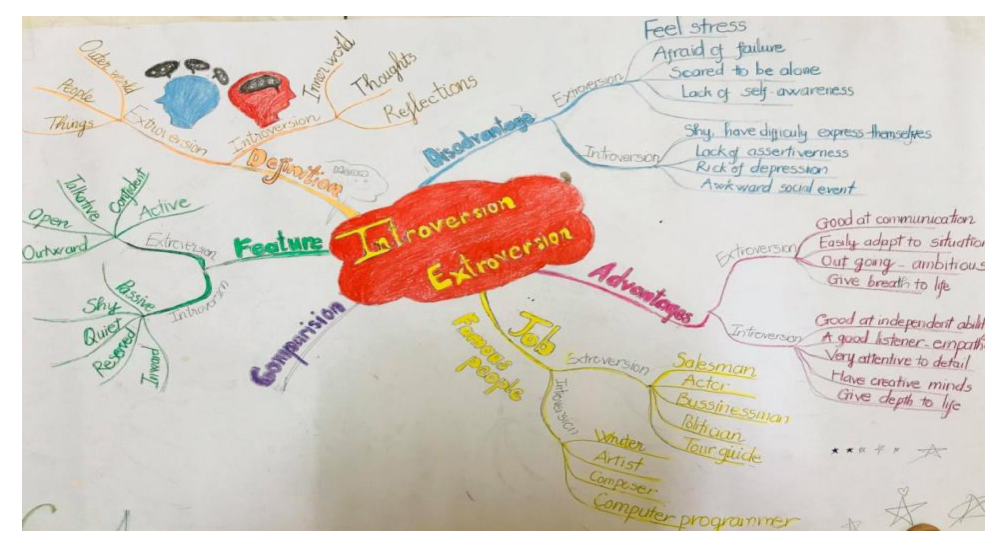

Image 1. A Model Mind Map Drawn by First-Year Students at Faculty of English

Mind mapping technique has also been considered to be an effective learning method when applied to written material. According to Buzan (2006), this technique is a visual tool that learners can use to generate and organize ideas, take notes, and develop concepts. It works by taking information from several sources and displaying this information as key words in a bright, colorful manner. De Porter, Reardon and Nourie (2008) also agree that this technique can help learners originate and extend ideas, and trigger the memory since both hemispheres of the brain are activated. In this way, mind mapping technique can help
EFL learners draw out their thinking naturally and form an association between ideas and vocabulary. Therefore, EFL students can benefit by making use of mind maps in speaking skill.

\section{Methodology}

\subsection{Aims of the Research}

This study aimed not only to explore the frequency, speaking stages, and freshmen's attitudes at FE, UFLS - UD when utilizing mind maps, but also to suggest a detailed procedure of using mind maps for students in EFL speaking classes. 


\subsection{Research Questions}

This study was conducted to answer three main questions specified as follows:

- What is the frequency of using mind maps in EFL speaking classes of the first-year students at FE, UFLS - UD?

- At which speaking stages do the first- year students at FE, UFLS - UD use mind maps in EFL speaking classes?

- What are the first-year students' attitudes towards using mind maps in EFL speaking classes at FE, UFLS - UD?

\subsection{Textbooks and Participants}

Table 1. Textbooks and participants

\begin{tabular}{ccccc}
\hline Time & Classes & $\begin{array}{c}\text { Number of } \\
\text { Students }\end{array}$ & Subjects & Textbooks \\
\hline Semester II & 18CNA07 & 40 & & Unit 7 - Unit 14 \\
February 2018 - May 2018 & 18CNA08 & 39 & GE 1.4 & PET Results \\
& 18CNA11 & 41 & & \\
Semester I & 19CNA05 & 42 & GE 1.1 & Unit 1 - Unit 5 \\
August 2018 - January 2019 & 19CNA07 & 38 & & Solution: Pre-Intermediate \\
& 19CNA10 & 40 & &
\end{tabular}

A glance at Table 1 given above illustrates the detailed information about the participants of this research which includes the semesters, classes, subjects, and relevant textbooks. The 240 first-year students of the Faculty of English, whose major is English Translation and Interpreting, and whose ages range from 18 to 20 years old, participated in this research. Half of the respondents have been studying English for 10 years, 100 first-year students have been exposed to English since they were at the age of 5 or 6 years old, the rest have experienced this language for 7 years. The study involved 225 female and 15 male participants. These 240 first-year students studied in 6 classes among the classes that the researchers were in charge and these 6 classes were selected to participate in the study randomly.

Two official textbooks including Solution - Pre Intermediate and PET Results written by Tim Falla and Paul A Davies, and Jenny Quintana respectively are being used for firstyear students at FE, UFLS - UD. Both are published by Oxford University Press. The first book is for General English (GE) namely $\mathrm{B} 1.1$ and B1.3, whereas the second one is for GE consisting of B1.2 and B1.4. These four courses are exam-oriented courses which provide first-year students with language proficiency at CEFR B1 level.

They had finished their first academic school years including 2017 - 2018, and 2018 - 2019; and were supposed to attain level 3, equivalent to level B1 of the CEFR test. These students were in six separate classes namely 18CNA07, 18CNA08, 18CNA11, 19CNA05, 19CNA07, and 19CNA10. The first three classes in semester II from February to May 2018 studied GE 1.4 including the last seven units of PET Results. In semester I from August 2018 to January 2019, the last three classes took part in the research studying GE 1.1 including the first five units of Solution: Pre-Intermediate.

\subsection{Research Methods}

\subsubsection{Data Collection}

There were three data collection instruments including questionnaires for freshman students 
and an interview at the end of each academic semester, and classroom observation during the 15 weeks of each semester.

The questionnaire comprised 6 questions with the aim of answering the research questions related to frequency, stages, and attitudes of the first-year students towards mind mapping technique. It was designed to be both closed and open-ended. In order to provide students with more opportunities to share all their thoughts relevant to the items in the questionnaire, the use of open-ended questions was a necessity since they could not give more ideas on their own to the questions if there were only close-ended ones. The interview questions aimed to support what the researchers observed.

Interview was conducted at the end of the semester after first-year students submitted the questionnaires investigating the frequency, stages, and attitudes of the participants. After first-year students submitted the questionnaires, each of the students was interviewed. That there were 240 first- year students as the participants led to 240 interviews since the researchers had to interview a student at a time.

Classroom observation was designed for the researchers to have an overview about the first two research questions including the frequency and stages of utilizing mind maps in EFL speaking classrooms. The students' attitude was not found out by this type of the data instruments. Unlike the other two data collection instruments, the researchers carried out the classroom observation during the learning process of the students.

\subsubsection{Procedure}

Step 1: The researchers observed the use of mind mapping technique of 6 classes during two semesters of each academic year 2017 - 2018 and 2018 - 2019. The researchers were in charge of 3 classes in semester II of the academic year $2017-2018$ and of 3 classes for the semester I of the academic year 2018 - 2019.

Step 2: During the semesters, researchers observed all these 6 classes. At the end of semester I and semester II, the same set of questionnaire was delivered to 240 different first year students of the two different academic years. After they finished the questionnaires, 240 first-year students were interviewed.

Step 3: After collecting the data, the researchers identified, and grouped them into categories. Then, they are displayed in percentage and illustrated by graphs. The data collected from the interview and classroom observation were qualitatively analyzed, whereas data from questionnaires were both quantitatively and qualitatively analyzed to answer the research questions.

Step 4: Based on the analysis of the data, the researchers came to conclusion about the use of mind maps in EFL speaking classes and then suggested a procedure where language teachers and learners could use mind maps to improve speaking skill.

\section{Results and Discussion}

\subsection{Frequency of Using Mind Maps in EFL Speaking Classes}

The research question related to the frequency of using mind maps in EFL speaking classes by first-year students at FE, UFLS UD was clarified by classroom observation of the researchers, interview questions and a set of the questionnaires for students.

What could be observed was that after having been instructed how to draw mind maps, all students made use of this technique to improve speaking skill with different rates of frequency. Therefore, most of the participants often used this technique. 
Table 2: Frequency of Using Mind Maps in EFL Speaking Classes

\begin{tabular}{ccc}
\hline Frequency & Occurrence & Percentage (\%) \\
\hline Always & 0 & $0 \%$ \\
Often & 192 & $80 \%$ \\
Sometimes & 34 & $14.17 \%$ \\
Rarely & 14 & $5.83 \%$ \\
Never & 0 & $0 \%$ \\
Total & 240 & 100 \\
\hline
\end{tabular}

Regarding the quantitative data from the questionnaire for students, it is evident from Table 2 that there was no student who always and never utilized mind maps in EFL speaking classes. The reasons why none of the students always used mind maps resulted from the difficulties they experienced when drawing mind maps as the researchers observed, namely limited ideas, inability to identify main and minor ones, lack of lexical resources, time constraint, and inability to brief ideas as key words. These obstacles collected from interviews contributed to the demotivation of the students to always use this method. Also, since students were aware of the benefits of mind maps in improving their speaking skill, there was no record of those who never used this technique. There were 192 students out of 240 accounting for $80 \%$ who revealed that they often took advantage of mind maps since mind maps could help them to brainstorm vocabulary, and extend speaking ideas by linking main ideas with supporting ones. Only 34 (14.17\%) and 14 (5.83\%) students sometimes and rarely used this technique respectively. The total proportion was exactly at $20 \%$ which was four times lower than those who often used mind maps accounting for $80 \%$ as mentioned above. This proved that using mind maps could reach first-year students' expectation to boost their speaking skill. The fact that a majority of them (80\%) who often made use of mind mapping technique proved its popularity with freshman students in EFL speaking classes.

\subsection{Stages of Using Mind Maps in EFL Speaking Classes}

A speaking lesson consisted of three stages namely pre-speaking, while-speaking, and post-speaking. To investigate the speaking stages at which first-year students used mind maps, the researchers observed, interviewed, and collected data from questionnaires.

Thanks to the first two data collection instruments, the researchers found out that the students used this technique mostly at pre-speaking and post-speaking, whereas the frequency of using mind maps at the while-speaking stage ranked the least. The speaking task types in the two textbooks for freshmen concentrate on particular aspects of oral interaction such as turn-taking, topic management, or situation making for oral interaction by pair or group work. They had a tendency to draw mind maps for topic management where they were asked to work individually. To other speaking activities requiring them to work in pairs or groups, they tended to make use of mind maps less than the former activities.

Looking at the pie chart in detail, Figure 1 highlighted the stages of a speaking lesson at which first-year students used mind maps whose data was from questionnaires. It is 
evident that $85 \%$ of students drew mind maps at the pre-speaking stage. Before answering a speaking question, they tended to draw a mind map of vocabulary related to the theme or topic of the speaking question. Post-speaking ranked the second at approximately $10.83 \%$ which was roughly eight times lower than the former. After having answered the speaking question, they added either more branches of ideas or more vocabulary to the original mind maps for later speaking practice. The bottom place belonged to the while-speaking stage at $4.17 \%$ which was about twenty times and three times lower than pre-speaking and post-speaking respectively. Even though a mind map could not be definitely drawn during their speaking performance, they tended to look at the mind maps in case they forgot the ideas. There was no shadow of doubt that mind mapping technique could be utilized at every stage of a speaking lesson with a different rate of frequency.

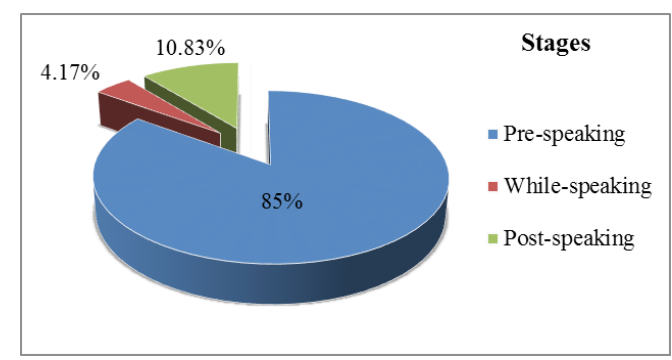

Figure 1. Stages of Using Mind Mapping

Technique

\subsection{Students' Attitudes towards Effectiveness of Using Mind Maps in EFL Speaking Classes}

Students' attitude towards the effectiveness of mind maps in EFL speaking classes was discovered by interview and questionnaires which was illustrated in Figure 2 below.

In the interview, most students advocated their interest in drawing mind maps for their oral speech performance since their speaking improvement was clearly seen by marks given by lecturers for speaking assessment at the end of the semester. Furthermore, they could know more thematic vocabulary and develop a logical sequence of talk. None of them thought mind mapping technique was not beneficial.

According to the figures on the bar chart, $100 \%$ of EFL freshman students enjoyed utilizing this technique to improve their oral speech performance with $51.25 \%$ of the "very effective" voters, $40.42 \%$ and $8.33 \%$ of the "extremely effective" and "moderately effective" ones respectively. There were no participants denying the effectiveness of this technique and considering it as a slightly effective technique to develop their speaking skill. In general, such proportion analyzed revealed the effectiveness of using mind mapping technique to improve students' speaking skill in EFL classes at FE, UFLS - UD.

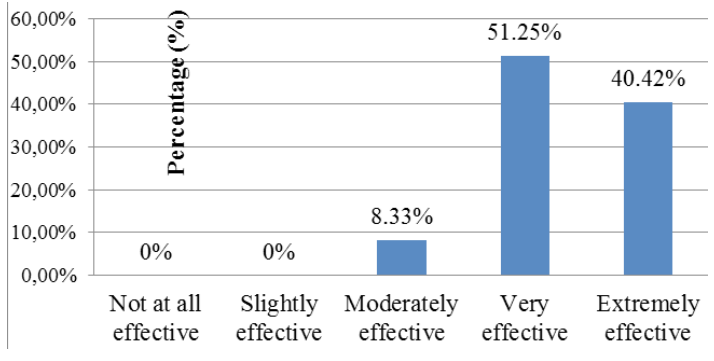

\section{Effectiveness}

Figure 2. Students' Attitudes towards Effectiveness of Mind Mapping Technique

\section{Suggestions and Conclusion}

\subsection{Suggestions}

\subsubsection{Simplified Mind Map Model}

An original mind map developed by Buzan should be drawn with different colors and images; however, students will find it difficult to change and modify the mind map if they make mistakes when drawing and the drawing 
length is really time consuming. Therefore, the researchers suggested the simplified mind map as in Figure 3 for students to apply in EFL speaking classes.

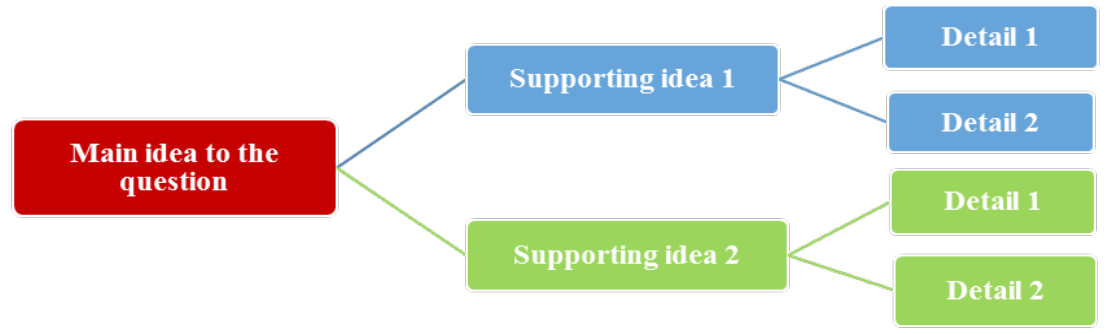

Figure 3. A Model Mind Map Suggested by Researchers

\subsubsection{Procedure Using Mind Maps in EFL Speaking Classes}

Together with the simplified mind map suggested in Figure 3, the researchers also designed a detailed procedure in which language teachers and learners draw mind maps to improve speaking skill.

Before performing the answer to a speaking question, students are required to list thematic vocabulary and ideas related to the question's content and topic. Subsequently, they have to draw a mind map with vocabulary and ideas they have just listed before. To make it more specific, students have to write down key words answering directly to the speaking question. This main idea is supported by two more sub-ideas and each supporting idea must have at least two additional details by giving examples, explanations, and quotes, or the statistics related to the subject in question.

For example, to answer the speaking question "What do you often do in your free time?", first-year students have to fill in the main idea box to directly answer the question "Reading books". The speaking question word is " $W h a t$ ", then to get ideas for supporting ideas, students should think of other two question words such as "Where do you read books in your free time?" and "Why do you read books in your free time?". Having thought of the other two sub-questions using other question words, students then have to fill in the two supporting ideas boxes in which supporting idea 1 will be replaced by "library at campus", and supporting idea 2 will be substituted by "widen knowledge". At the first branch "library at campus", students must add more information related to the reason why they choose reading books at the campus. Detail 1 and detail 2 will be then replaced by "variety of books", and "quiet environment" respectively. At the latter branch "widen knowledge", detail 1 and detail 2 will be "academic" and "general". All the steps described above will be demonstrated in Figure 4 in detail.

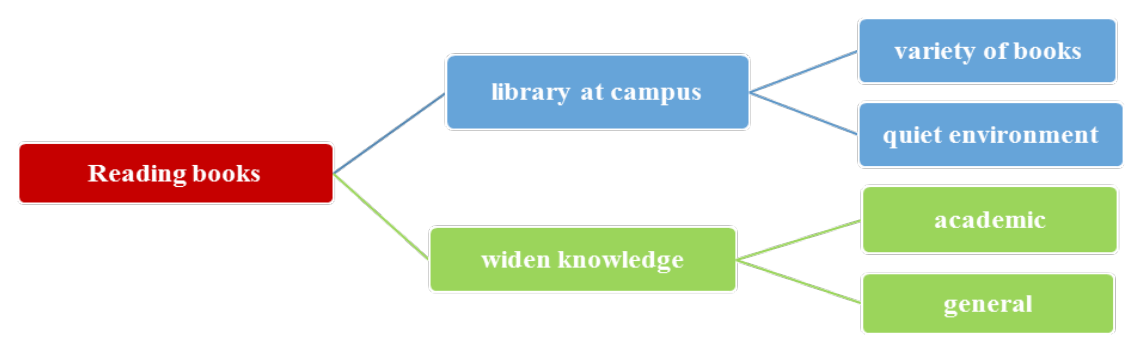

Figure 4. A Mind Map with Speaking Ideas Developed by Students 
Once the mind map is accomplished, firstyear students have to answer the speaking question. In case they can remember ideas in the mind map, there is no need to look at it. However, they can look at the mind map if they cannot recall ideas.

In the post-speaking stage, language teachers can require students to add more vocabulary to the mind map, and then write down a short paragraph generating ideas from the mind map. Below is a short paragraph written by a first-year student based on the mind map in Figure 5.

I often read books whenever I have spare time. Where I often read books is the library campus at my university - The University of Foreign Language Studies in Luong Nhu Hoc Street. There are two reasons why I enjoy reading books at the library. You know, there is a variety of books, articles, and journals related to my major which I can easily find out. The second motive that should be taken into consideration is the reading environment. Every student in the library has to be quiet. Library readers are not allowed to make noise; therefore, I can possibly pay attention to what I am reading and that is really amazing. You know why I am really into reading books since I can widen my horizon for academic and general knowledge.

Once students finish writing paragraphs, they are asked to record their answer and send the recording files to their teachers for assessments. Language teachers will then make comments, email or give feedback on students' speaking performances to them in person.

\subsection{Conclusion}

In order to answer the research questions related to the reality of using mind mapping technique of the freshman students after being instructed to implement this learning method in speaking, the researchers delivered a set of questionnaire with 7 questions to 240 freshman students, and conducted the interview at the end of each semester, and observed the EFL speaking classes during two academic school years 2017 - 2018, and 2018 - 2019. Following are the conclusions based on the analysis of the data collected in this research and focusing on the frequency, speaking stages, and students' attitudes towards the use of mind maps in EFL speaking classes of first-year students at FE, UFLS - UD.

- There was a significant difference in the frequency of using mind maps in which most first-year students often used this technique in their speaking process. Neither of them always nor never drew mind maps since this technique was associated with certain difficulties, which could inhibit learning and demotivate students to study, namely their shortage of thematic vocabulary, inability to think of main and minor ideas, time length to draw a mind map, and their terrible drawing skill.

- However, once it was used, students drew mind maps mostly in the prespeaking phase to recall or list relatedtopic vocabulary and to develop a logical sequence of ideas when speaking. Postspeaking and while speaking stages ranked the second and the least respectively. Firstyear students tended to draw mind maps to perform speaking activities which required them to work individually on such tasks as topic management. In speaking activities which required interaction among students, mind maps were taken advantage of less than the individual work.

- This technique can be a useful one for EFL learners since all of the first-year students advocated its effectiveness at different levels to develop their English speaking skill. View taken from students taught through the use of mind maps was positive. 


\section{References}

Anggraeni, A. D. (2019). Blended Humor and Mind Mapping in Improving 21st Century Skills. Jurnal Ilmu Pendidikan, 25(1), 1-5.

Baker, J., \& Westrup, H. (2003). Essential speaking skills: A handbook for English language teachers. London: Continuum.

Burns, A., \& Joyce, H. (1997). Focus on speaking. Sydney: National Center for English Language Teaching and Research.

Buzan, T. (2005). Smart book mind map. Jakarta: Gramedia.

Buzan, T. (2006). The mind map book. London: Pearson Education.

Chaney, A. L., \& Burk, T. L. (1998). Teaching Oral Communication in Grades K-8. Boston: Allyn and Bacon.

DePorter, B., Reardon, M. \& Singer-Nourie, S. (2008),

Quantum teaching: Mempraktikkan quantum learning di ruang ruang kelas (A. Nilandari, Trans.). Bandung: PenerbitKaifa PT MizanPustaka.

Ellis, R. (2008). The study of second language acquisition. Oxford: Oxford University Press.

Heaton, J. B. (1988). Writing English language test. New York: Longman.

Howarth, P. (2001). Process Speaking. Preparing to Repeat Yourself. Modern English Teacher, 10(1), 39-44.
Mirza, A. (2017). The Use of Mind Mapping Strategy to Improve Students' Speaking Ability. Doctoral dissertation, UIN Ar-Raniry Banda Aceh.

Nasution, D. S. (2020). Mind Mapping to Improve Students' Speaking Skill. English Education: English Journal for Teaching and Learning, 8(1), 1-12.

Nunan, D. (1999). Second language teaching and learning. Boston, Massachusetts: Heinle \& Heinle.

Rachmawati, M., Nugrahaeni, F., \& Mauludiyah, L. (2020). Improving Arabic Speaking Skill through Mind Mapping Strategy. Izdihar: Journal of Arabic Language Teaching, Linguistics, and Literature, 3(1), 31-44.

Richards, J. C., \& Rodgers, T. S. (2001). Approaches and methods in language teaching. Cambridge: Cambridge University Press.

Richards, J. C. (2008). Teaching listening and speaking: From theory to practice. Cambridge: Cambridge University Press.

Shumin, K. (2002). Factors to consider: Developing adult EFL students' speaking abilities. In J. C. Richards, \& W. A. Renandya (Eds.), Methodology in Language Teaching (pp. 204-211). New York: Cambridge University Press.

\title{
SỬ DỤNG SƠ ĐỒ TỦ DUY TRONG KĨ NĂNG NÓI TẠI KHOA TIẾNG ANH, TRƯỜNG ĐẠI HỌC NGOẠI NGŨ̉ - ĐẠI HỌC ĐÀ NÃNG
}

\author{
Phan Văn Hòa, Ngô Thị Hiền Trang
}

\author{
Trường Đại học Ngoại ngũu - Đại học Đà Nã̃ng \\ 131 Luoong Nhũ Hộc, Khuê Trung, Cẩm Lệ, Đà Nã̃ng, Việt Nam
}

Tóm tắt: Nói, một trong hai kỹ năng sản sinh ngôn ngữ, được sinh viên năm thứ nhất tại Khoa tiếng Anh, Trường Đại học Ngoại ngữ - Đại học Đà Nẵng đặc biệt quan tâm. Người dạy và người học ngôn ngữ sử dụng nhiều phương pháp khác nhau để phát triển kỹ năng này, trong đó có sơ đồ tư duy. Sơ đồ tư duy có thể hỗ trợ người dạy và người học ngôn ngữ cải thiện chất lượng học các kỹ năng ngôn ngữ nói chung và kỹ năng nói nói riêng. Hiện tại, sơ đồ tư duy được sinh viên năm thứ nhất sử dụng trong các tiết học nói để cải thiện kỹ năng này. Tác giả bài báo cho rằng sử dụng sơ đồ tư duy có tác động tích cực giúp nâng cao kĩ năng nói cho sinh viên năm thứ nhất tại Khoa tiếng Anh. Chúng tôi tiến hành nghiên cứu sử dụng phương pháp định lượng và định tính từ nguồn dữ liệu được thu thập thông qua các câu hỏi phỏng vấn, phiếu điều tra và quan sát lớp học. Tác giả chọn đề tài "Sủ dụng sơ đồ tu duy trong kĩ năng nói tại Khoa tiếng Anh, truờng Đại học Ngoại ngũ " với mục đích tìm hiểu sinh viên năm thứ nhất Khoa tiếng Anh có thường xuyên sử dụng sơ đồ tư duy, ở những giai đoạn nào, và thái độ của các em khi sử dụng sơ đồ tư duy để cải thiện kĩ năng nói. Đề xuất của nghiên cứu có thể ứng dụng trong dạy và học tiếng Anh, đặc biệt để giúp sinh viên phát triển hiệu quả kĩ năng nói của sinh viên chuyên ngữ tại Khoa tiếng Anh nói chung, và sinh viên năm thứ nhất nói riêng.

Tù khóa: giai đoạn, kỹ năng nói, tần suất, thái độ, sinh viên năm thứ nhất, sơ đồ tư duy. 


\section{APPENDIX 1}

\section{CLASSROOM OBSERVATION SHEET}

Date:

Unit:

School:

Period:

Class:

Textbook:

Teacher in charge:

Time length:

\begin{tabular}{|c|c|c|c|c|}
\hline \multicolumn{5}{|c|}{ Stages of Using Mind Mapping Techniques } \\
\hline \multicolumn{7}{|c|}{ Pre-speaking } & While- speaking & \multicolumn{2}{c|}{ Post- speaking } \\
\hline \multicolumn{5}{|c|}{ Frequency of Using Mind Mapping Techniques } \\
\hline Always & Often & Sometimes & Rarely & Never \\
\hline & & & & \\
\hline
\end{tabular}

\section{APPENDIX 2}

\section{INTERVIEW QUESTIONS}

Date:

Unit:

School:

Period:

Class:

Textbook:

Teacher in charge:

Time length:

Question 1: What is the frequency of using mind maps in EFL speaking classes of the firstyear students at FE, UFLS - UD?

Question 2: At which speaking stages do the first-year students at FE, UFLS - UD use mind maps in EFL speaking classes?

Question 3: What are the first-year students' attitudes towards using mind maps in EFL speaking classes at FE, UFLS - UD?

\section{APPENDIX 3}

\section{QUESTIONNAIRE}

With the aim of investigating the use of mind mapping technique of the first year students in EFL speaking classes at the Faculty of English, University of Foreign Language Studies - The University of Danang, the researchers would highly appreciate your cooperation in completing this questionnaire. Your answers by putting a tick in the following boxes according to your opinions are valuable for the research. You can be sure that all your comments and ideas are confidential and just used for this research not for any other purposes.

\section{Personal questions}

1. How old are you?

$$
\square 20
$$


$\square$ Over 20

2. How long have you learnt English?

$$
\begin{aligned}
& \square 3 \text { years } \\
& \square 7 \text { years } \\
& \square 10 \text { years } \\
& \square \text { More than } 10 \text { years }
\end{aligned}
$$

\section{Questionnaire on using mind mapping technique in speaking}

1. Do you think it is necessary to use mind mapping technique in speaking?

$\square$ Yes

$\square$ No

2. How often do you use mind mapping technique in speaking?

$$
\begin{aligned}
& \square \text { Always } \\
& \square \text { Often } \\
& \square \text { Sometimes } \\
& \square \text { Rarely } \\
& \square \text { Never } \\
& \square \text { Others:......... }
\end{aligned}
$$

3. At what stage do you use mind mapping technique in speaking (more than one answer is possible)

$\square$ Pre-speaking stage

$\square$ While- speaking stage

$\square$ Post- speaking stage

$\square$ Others:

4. In your opinion, using mind mapping technique in reading comprehension is:

$$
\begin{aligned}
& \square \text { Extremely effective } \\
& \square \text { Very effective } \\
& \square \text { Moderately effective } \\
& \square \text { Slightly effective } \\
& \square \text { Not effective at all } \\
& \square \text { Others: }
\end{aligned}
$$

